\title{
The Effects of Socio-Economic Factors on the Demand for Anadolu University Open Education System
}

\author{
Sosyoekonomik Faktörlerin Anadolu Üniversitesi Açıköğretim Sistemi Talebi Üzerindeki \\ Etkisi
}

\author{
Bahar BERBEROĞLU*, Rabia Ece OMAY', \\ C. Necat BERBEROĞLU $\&$ Çağlar KARADUMAN ${ }^{\S}$
}

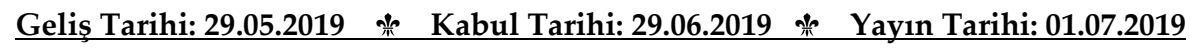

\begin{abstract}
The aim of this study is to put forward how the demand for Anadolu University Open Education System is affected by socio-economic factors in the provinces of Turkey. We tried to construct a structural equality model which is called as path analysis. First, factor analysis was applied to socioeconomic variables which were obtained in province basis and three important factors were found. These are the levels of economic development, labor and education in the province. Then, multiple regression analysis was performed between these factors and the variables of Anadolu University Open Education System. As the result of the analysis, we found that economic development and education variables positively affect the demand for Anadolu University Open Education System while labor variables affect negatively. Thus, we have shown the positive contributions of economic development and education levels of the province to the demand for Open Education System. It is not surprising that individuals in the workforce do not benefit from open education. Because, individuals after increasing their skills through open education, generally leave education and join the workforce, with the intention of finding a new job or new initiatives to be employed.
\end{abstract}

Keywords: Anadolu university open education system, factor analysis, regression analysis, path analysis, structural equality models

\footnotetext{
* Prof. Dr., Anadolu Üniversitesi, Açıöğretim Fakültesi, Eskişehir, Türkiye. E-mail: bdirem@anadolu.edu.tr

+ Doç. Dr., Dokuz Eylül Üniversitesi, İktisadi ve İdari Bilimler Fakültesi, İzmir, Türkiye

‡ Prof. Dr., Anadolu Üniversitesi, Emekli Öğretim Üyesi

$\S$ Araş. Gör. Dr., Anadolu Üniversitesi, İktisat Fakültesi, Eskişehir, Türkiye.
} 


\section{Özet}

Bu çalışmanın amacı Türkiye'de il bazında Anadolu Üniversitesi Açıöğretim Sistemi'nin sosyoekonomik faktörlerden nasıl etkilendiğini ortaya koymaktır. Bunun için faktör analizi ve regresyon analizini kullanarak bir yapısal eşitlik modeli oluşturduk. Bu tür yapısal eşitlik modellerine yol (path) analizi adı verilmektedir. Böylelikle il bazında elde edilen sosyoekonomik değişkenlere faktör analizi uygulanmıştır. Bu analiz sonucunda üç önemli faktör elde edilmiştir. Bunlardan birinci faktör ilin ekonomik gelişme düzeyini, ikinci faktör işgücünü ve üçüncü faktör eğitim düzeyini göstermektedir. Bu faktörlerin Anadolu Üniversitesi Açıöğgretim Sistemi'ne yönelen talebi nasıl etkilediğini regresyon analizini kullanarak değerlendirdiğimizde ekonomik gelişme ve eğitim faktörlerinin pozitif ve işgücü faktörünün negatif olarak etkilediğini gördük. Böylece bir ilin ekonomik gelişme düzeyinin Açıöğretim Sistemi'ne olan olumlu katkısını ortaya koymuş olduk. Bunun dışında eğitim altyapısı olan illerin Açıö̆ğretim Sistemi'ne yöneldiği söylenebilir. İşgücüne dâhil olan bireylerin Açıö̆ğretim Sistemi'ne yönelmemesi ise şaşırtıcı bir sonuç değildir. Çünkü istihdam edilmeyenlerin Açıöğretim Sistemi'ne dâhil olması ve bu sayede niteliğini geliştirmeye çalışması beklenilen bir durumdur.

Anahtar Kelimeler: Anadolu üniversitesi açıköğretim sistemi, faktör analizi, regresyon analizi, yol analizi, yapısal eşitlik modelleri

\section{Introduction}

In classical economic theory, the concept of capital was explained as the sum of physical capital assets consisting of machinery, equipment and other equipment besides cash capital. However, these values are gathered under the name of Human Capital as a result of increasing importance of personal, social and social characteristics to production. Those positive values mentioned here are the levels of knowledge, skills and experience in the workforce. In this respect, the concept of human capital, which constitutes the main source of economic growth and development, is used to refer to all concepts such as knowledge, skills, abilities, health status, place in social relations and level of education of individuals or a society (Taş and Yenilmez, 2008).

While human capital contributes to the social dimension of the development process by creating a change in behavior, it also contributes to the economic development as the most important input of the production process (Özgür, 2005). For this reason, the continuity of the formation, accumulation and development of human capital constantly promotes socioeconomic development and brings societies and their countries to prosperity (Taş and Yenilmez, 2008). These socioeconomic developments may be at the country level but also at regional and provincial levels.

The level of education of the labor force is an extremely important factor affecting both the quality of economic activities and labor force participation rates. Today, as the general education level of a country's workforce increases, the labor force participation rate in that country also increases (Kavak, 1990). The level of education of the workforce, which increases the productivity of the workforce, and thus increases the wages and job opportunities, and decreases the risks of being unemployed, 
constitute the source of the significant increases in the individual earnings due to these important contributions to the work life. Increasing the level of education of the labor force within these aspects is an effective policy tool in the fight against unemployment and poverty, especially in developing countries (Çalışkan, Karabacak and Meçik, 2013). As lifelong learning and open and distance learning methods are used to benefit not only young people but also older people, the level of education, knowledge and skills of the whole workforce can be increased this way.

On the other hand, it is known that the labor force participation of young people and the phenomenon of unemployment among young people are closely related to their decision to attend or participate in business life. For example, the high labor force participation rate reflects the high expectations of young people about completing school and moving to work life, while the high unemployment rates among young people can often force young students to stay longer in school (OECD, 1995). However, lifelong learning and open and distance education methods can also affect young people's decisions to be completed or sustainable at any age.

While the increases in human capital contributed significantly to the foreign trade with economic growth and economic development levels, the developments in these issues undoubtedly create a feedback effect for the increase of human capital accumulation. As is known, Verdoorn's law states that there is a positive relationship between growth in productivity and growth in output. Such a relationship creates a comparative advantage in exports. Furthermore, Mincer (1996) argues that the resources that feed the growth of human capital are in a direction to provide economic development. Thus, it should not be overlooked that the increase in human capital has emerged not only as a cause of economic growth but also as a result of economic growth (Şimşek and Kadılar, 2010).

This study aims to put forward how Anadolu University Open Education System is affected by socio-economic factors in Turkey, within a provincial frame. We used a factor analysis and regression analysis to construct a structural equality model. Such structural equality models are called "path analysis". Thus, as of 2013, factor analysis was applied to socioeconomic variables obtained on the basis of provinces. As a result of this analysis, three important results were obtained. The first one indicates the economic development level of the province, the second one indicates the workforce and the third one represents the level of education. When we evaluated how these factors affect the demand directed to Anadolu University Open Education System by using regression analysis, we observed that economic development and education factors affect this demand positively, whereas labor force factor negatively affected. Thus, we have demonstrated the positive contribution of the level of economic development of a province to the Open Education System. On the other hand, based on our findings, it can be said that the provinces with good educational infrastructure are oriented towards the Open Education System. It is not surprising that individuals who are involved in the labor force do not turn to the Open Education System. Because 
it is expected that those who are not employed have a higher probability to be in the Open Education System, trying to improve their quality.

\section{The Relation Between Education and Economy}

When someone wants to evaluate an extraordinarily large and comprehensive issue such as the relationship between education and the economy in general, he or she will undoubtedly need to establish some basic headings in order to be able to tackle the issue firstly.

Our first title on the relationship between education and the economy may be the impact of education on economic development. Economic development strategies to be applied in an economy cannot be applied separately from education policies. In other words, the main differences between the economic development policies of each country stem from the perspectives of these countries on education. Therefore, using economic development policies, developing countries use education policies as a tool in development strategies (Seyidoglu, 1993).

A second title should be to ensure that the labor force and societies can keep up with the rapid change experienced in all societies today through education. In the face of rapid technological advances and innovations, it is not only a matter of developing countries but also in developed countries that have the knowledge and skills to use these innovations. This problem can be solved by properly selected and effectively implemented training policies.

The relationship between education and employment is a very important issue too. As is known, the training of qualified manpower and the continuous development and renewal of its qualifications is one of the main tasks of the education system. Higher education educates highly qualified manpower while vocational high schools and vocational and technical education institutions train qualified manpower, and various non-formal and open education institutions function for labor force to gain the skills needed by the sector.

The income-enhancing and income-equalizing characteristics of education helps solving one of the most important elements of the efforts to improve the income distribution and income distribution and the fight against poverty and the improvement of income distribution of education in a country. The characteristics of education that provide this privilege are that education is one of the most important factors that provide micro-level individual income and accelerate economic development at macro level (Taş and Yenilmez, 2008). On the other hand, the general structure of economies affects the relationship between education and personal income distribution. When the share allocated to education increases, inequality in income distribution decreases and national income growth rises. However, proportional differences between educational levels in various countries are also 
effective. The more accurate the pyramid showing the education levels, the more it is the effect of education on income distribution and the increase in national income (Kasliwal, 1995).

Due to the rapid progress of technology in the world together with globalization, countries are trying to get a share from the international market in a tough competition environment. This can be achieved by producing high-quality goods and services, improving the quality of the product and using better qualified workforce. In this sense, undoubtedly, the relationship between education and economy and technology is gaining importance and human resources have to be developed and efficiency should be increased in order to increase the competitiveness of a country and to take place in the world economy (Taş and Yenilmez, 2008).

The contribution of education to the economy as well as the reflections of the economy on education or the mutual interaction of these relations in both directions has been supported by many studies in the literature so far.

Barro, who has penned some of the pioneering work on education and economic development, has demonstrated a strong positive relationship between education and economic growth (Barro, 1991). Barro and Sala-i-Martin reported that the average of access to education, measured by the average periods at the middle and college level, tended to show a significant relationship with economic growth (Barro and Sala-iMartin, 1995).

Authors of studies on the causal relationship between economic growth and education in Turkey, Kar and Ağır (2003), Taban and Kar (2006) with Beşkaya, Savaş and Şamiloğlu (2010) put forward that both education and economic growth mutually affect each other.

In their study, Bils and Klenow examined the causal relationship between education and economic growth and found a two-way relationship, and emphasized that the effect of education on growth is more dominant than education (Bils and Klenow, 2000).

Şimşek and Kadılar, in line with endogenous growth theory, found that the accumulation of human capital supports long-term economic growth, on the other hand, economic growth has increased the accumulation of human capital. (Şimşek and Kadilar, 2010).

We argued that education may have a contribution to the economy, or that the economy may have reflections on education. Using the economic opportunities of the state, it should provide education service to the service of everyone in the country, to make schools, to employ the education and teaching staff to provide education service, to pay satisfactory salary to the education and training army employed, and to ensure that the physical conditions of the students and the environment of the teachers have sufficient conditions. In addition, while the information and communication technologies in the globalized world are advancing rapidly, the widespread use of 
these technologies in the field of education and training makes it difficult for states to gain access and spread the technology to the base. Undoubtedly, the capability to overcome this difficulty depends on the economic power of the countries. It is also important that the state allocates its existing economic opportunities to different sectors and allocates a required level of education and training.

\section{Method}

Structural Equality Modeling Method is the most appropriate method in our case. Because, especially when if a dependent variable is to be taken as an independent variable in the next commitment relationship such model should be chosen (Orhunbilge, 2010). Structural equality models have a significant advantage in describing complex structures and latent relationships between variables, transforming them into a new variable and defining new relationships between these variables.

Path analysis is a kind of analysis which consists of a combination of factor analysis and multiple regression analysis and has an important role in structural equation models. Since the regression coefficients are naturally asymmetrical, it has been seen that the causal effects are more appropriate for the correlation coefficients. This view led to the development of the Path Analysis Method (Orhunbilge, 2010).

In the cause-effect relationship between the two variables, it is important to determine which variable or variables are the cause of the variable, and which variable or variables should be considered as the result variable. Therefore, this relation should be determined by the researcher and the analysis should be done accordingly (Pek, 1999).

Analyzes such as correlation or regression are also used in the analysis of the relationships between variables. However, due to the limitations of correlation and regression analysis, path analysis has been widely used recently. Path analysis allows the separation of direct and indirect relationships between dependent and independent variables and control of the error variable (Brannick, 2009).

\section{Variables used in analysis}

\section{Explanatory variables}

X1: Labor Force Participation Rate. This is the ratio of the labor force to the active population. Labor is the sum of the working population and the unemployed and looking for a job. The active population is the population over the age of 15 excluding those living in places such as dormitories, hospitals, barracks or prisons. This ratio is calculated as:

Labor force participation $=$ Workforce $/$ Non-institutional working age population 
X3: Employment Rate. This is the ratio of the employed population to the noninstitutional working age population.

X8: Net Schooling Rate in Primary Education. The net school enrollment rate is calculated as: students in the theoretical age group defined for primary education are divided into total population (age population) in the theoretical age group defined for primary education and multiplied by 100.

X9: Net Schooling Rate in Secondary Education. The net school enrollment rate calculated as: the students who are in the theoretical age group defined for secondary education are divided into total population (age population) in the theoretical age group defined for secondary education and multiplied by 100 .

X11 and X12 are the National Market Access Index. Let us first explain this concept and then evaluate the meanings of to spread and attraction.

There may be differences in the volume of trade between countries as well as inter-regional differences in terms of physical, human and geographical conditions, unbalanced distribution of population, differences in agricultural production or accumulation of industrial activities in certain regions. The National Market Accessibility Index measures the differences in domestic trade volume due to differences in physical, human, geographical conditions and unbalanced distribution of population, differences in agricultural production or agglomeration of industrial activities in certain regions.

It is known that regions close to major markets in a country are more developed because they use the market advantage over remote regions. Moreover, it can be said that different transportation infrastructures affect the economic performance of the regions significantly. With the effect of transportation costs in different regions of a country, production costs differ and there may be difficulties in terms of access to the market in regions outside the country's non-centralized regions. Therefore, it may be possible in places with difficulties to reach national markets that the economic performance being at a lower level compared to other regions.

The difference between transport infrastructure and market access resulting from the causes of disparities between western and eastern regions in Turkey are important issues. It is possible to say that the problem of inadequate market integration has decreased significantly with the expansion of the transportation network in our country, increasing access of the provinces to the coasts, strengthening of the northsouth highway connections, expansion of the area covered by air transportation and the development of information and communication technologies. The effective transportation connections provided as a result of the investments made in the transportation sector in our country have enabled the creation and deepening of the domestic market. However, there are still things to be done to effectively integrate the transport systems of the eastern and western and northern and southern regions of our country and to ensure market integration. 
The concept of accessibility to the national market, from another point of view, shows the cost of reaching all the destinations that an individual can travel from the point of origin. The closer a region is to its core business, the higher the value of access to the national market. Accordingly, the accessibility of provinces to the national market is calculated by the following formula:

$$
A(N M)=\sum_{i}^{n} P_{i}+\sum_{j}^{n} P_{j} / d_{i j}
$$

Here; $A(N M)$ : Access to the national market

$\mathrm{d}_{\mathrm{ij}}$ : distance between province $\mathrm{i}$ and province $\mathrm{j}$

$P_{j}:$ population of province $j$

$\mathrm{n}$ : the number of provinces

L: refers to the distances matrix (81X81).

X11: Accessibility Index for National Market in Terms of Diffusion. Accessibility in terms of diffusion is defined as the capacity to access from one province to other provinces. The accessibility capacity of a province in terms of expansion can be expressed as the potential relations between two provinces calculated using the sum of the total population in a province and the distance between the provinces on the base of province.

X12: Accessibility Index for National Markets in Terms of Attractiveness. The accessibility to a province from another one. The accessibility capacity of a province in terms of attraction can be expressed as the sum of the potential relations of a province with other provinces by using the total population of a province and road distances between provinces.

The transport infrastructure plays an important role in resolving the backwardness of a settlement. In this respect, transportation is considered as an important policy tool for regional development. The development and quality of transportation infrastructure may affect the investment preferences of firms due to transportation costs, the intensity of commercial relations, the efficiency of enterprises and the concentration of investments in a region, and may create differences between the regions in economic growth and welfare increase (Şimşek, 2015).

X13: Public Investment Rate of Provinces. This ratio was calculated with this formula:

(Provincial public investment / public investment average for the provinces). 100

X14: Average Export Rate (\$). This ratio was calculated with this formula:

The export value of each province is divided by the average export value of 81 provinces and multiplied by 100 . 
X15: Average Import Rate (\$). The import value of each province is divided by the average import value of 81 provinces and multiplied by 100 .

X19: Motorized Land Transport Rate in Traffic. This value is calculated regarding "Motor Traffic Law" in our country and all motor vehicles that are obliged to get registration certificate from the traffic authorities and whose registrations are connected to the General Directorate of Security.

It is particularly important how the interrelationships of the independent variables are. In particular, if we intend to apply path analysis, it will be necessary to take a look at the correlations between the variables and then carry on the analysis that these can combine to form one factor. The correlation matrix for the independent variables is shown as follows:

Table 1. Correlations

\begin{tabular}{|c|c|c|c|c|c|c|c|c|c|c|c|}
\hline \multicolumn{12}{|c|}{ Correlations } \\
\hline & & $\mathrm{x} 1$ & $\mathrm{x} 3$ & $\mathrm{x} 8$ & $x 9$ & $\mathrm{x} 11$ & $\mathrm{x} 12$ & $\mathrm{x} 13$ & $\mathrm{x} 14$ & x16 & $\mathrm{x} 19$ \\
\hline \multirow[t]{4}{*}{$\mathrm{x} 1$} & Pearson & 1 & $978^{* *}$ & ,066 & 217 & 012 & ,129 &,- 142 & ,053 & 012 & , 097 \\
\hline & Correlation & & & & & & & & & & \\
\hline & Sig. (2-tailed) & & ,000 &, 557 & ,051 & ,916 & ,250 & ,205 & ,640 & ,918 & ,390 \\
\hline & $\mathrm{N}$ & 81 & 81 & 81 & 81 & 81 & 81 & 81 & 81 & 81 & 81 \\
\hline \multirow[t]{4}{*}{$\mathrm{x} 3$} & Pearson & $978^{* *}$ & 1 & ,015 & 215 &,- 046 & 100 &,- 199 & ,008 &,- 047 & 042 \\
\hline & Correlation & & & & & & & & & & \\
\hline & Sig. (2-tailed) & ,000 & & 896 & ,054 & 686 & 374 & 075 & ,941 & 675 & 712 \\
\hline & $\mathrm{N}$ & 81 & 81 & 81 & 81 & 81 & 81 & 81 & 81 & 81 & 81 \\
\hline \multirow[t]{4}{*}{$\mathrm{x} 8$} & Pearson & ,066 & ,015 & 1 & $306^{* *}$ & 136 &,- 009 & , 149 & , 074 & 134 & , 120 \\
\hline & Correlation & & & & & & & & & & \\
\hline & Sig. (2-tailed) &, 557 & 896 & & ,006 & ,227 & ,937 & , 185 & ,512 & ,232 & ,288 \\
\hline & $\mathrm{N}$ & 81 & 81 & 81 & 81 & 81 & 81 & 81 & 81 & 81 & 81 \\
\hline \multirow[t]{4}{*}{$x 9$} & Pearson & ,217 & ,215 & $306^{* *}$ & 1 & 133 & 202 & 100 & ,094 & 120 & , 170 \\
\hline & Correlation & & & & & & & & & & \\
\hline & Sig. (2-tailed) & ,051 & ,054 & ,006 & & ,235 & , 070 & ,372 & ,403 & ,286 & ,129 \\
\hline & $\mathrm{N}$ & 81 & 81 & 81 & 81 & 81 & 81 & 81 & 81 & 81 & 81 \\
\hline \multirow[t]{4}{*}{$x 11$} & Pearson & ,012 &,- 046 & ,136 & 133 & 1 &, $753^{* *}$ &, $773^{* *}$ & $909^{* *}$ &, $992^{* *}$ &, $977^{* *}$ \\
\hline & Correlation & & & & & & & & & & \\
\hline & Sig. (2-tailed) & 916 & 686 & 227 & ,235 & & , 000 & , 000 & , 000 & , 000 & , 000 \\
\hline & $\mathrm{N}$ & 81 & 81 & 81 & 81 & 81 & 81 & 81 & 81 & 81 & 81 \\
\hline \multirow[t]{4}{*}{ x12 } & Pearson & ,129 & 100 &,- 009 & ,202 &, $753^{* *}$ & 1 & $420^{* *}$ &, $767^{* *}$ & ,740* & ,740** \\
\hline & Correlation & & & & & & & & & & \\
\hline & Sig. (2-tailed) & 250 & 374 & ,937 - r & ,070 & , 000 & & 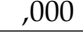 & 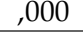 & , 000 & , 000 \\
\hline & $\mathrm{N}$ & 81 & 81 & 81 & 81 & 81 & 81 & 81 & 81 & 81 & 81 \\
\hline \multirow[t]{4}{*}{$x 13$} & Pearson &,- 142 &,- 199 & 149 & ,100 &, $773^{* *}$ & $420^{* *}$ & 1 &, $530^{* *}$ &, $727^{* *}$ &, $744^{* *}$ \\
\hline & Correlation & & & & & & & & & & \\
\hline & Sig. (2-tailed) & ,205 & ,075 & , 185 & ,372 &, 000 &, 000 & & ,000 & ,000 & ,000 \\
\hline & $\mathrm{N}$ & 81 & 81 & 81 & 81 & 81 & 81 & 81 & 81 & 81 & 81 \\
\hline \multirow[t]{4}{*}{ x14 } & Pearson & ,053 & , 008 & 074 & ,094 &, $909^{* *}$ &, $767^{* *}$ &, $530^{* *}$ & 1 &, $938^{* *}$ &, $888^{* *}$ \\
\hline & Correlation & & & & & & & & & & \\
\hline & Sig. (2-tailed) & ,640 & ,941 &, 512 & ,403 & , 000 &, 000 &, 000 & & ,000 & ,000 \\
\hline & $\mathrm{N}$ & 81 & 81 & 81 & 81 & 81 & 81 & 81 & 81 & 81 & 81 \\
\hline \multirow[t]{4}{*}{$x 16$} & Pearson & ,012 &,- 047 & 134 & ,120 & , $992^{* *}$ &, $740^{* *}$ &, $727^{* *}$ &, $938^{* *}$ & 1 &, $978^{* *}$ \\
\hline & Correlation & & & & & & & & & & \\
\hline & Sig. (2-tailed) & ,918 & ,675 & ,232 & ,286 & , 000 &, 000 & ,000 &, 000 & & ,000 \\
\hline & $\mathrm{N}$ & 81 & 81 & 81 & 81 & 81 & 81 & 81 & 81 & 81 & 81 \\
\hline x19 & $\begin{array}{l}\text { Pearson } \\
\text { Correlation }\end{array}$ & ,097 & ,042 & 120 & 170 &, $977^{* *}$ &, $740^{* *}$ &, $744^{* *}$ &, $888^{* *}$ &, $978^{* *}$ & 1 \\
\hline
\end{tabular}




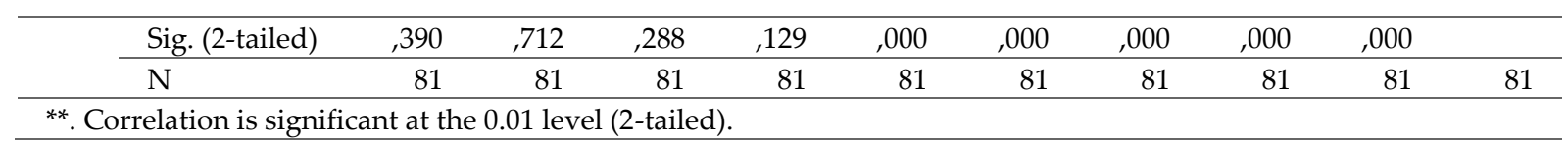

\section{Independent variables}

Y1 (new registration): The normalization value (proportional value) of the first enrolled students in Anadolu University Open Education Faculty

Y2 (additional placement): The normalized value of the number of students admitted to departments which are not filled with quota or empty due to the fact that the quota of Anadolu University is full but the final registration is not done. Or normalized value of the number of students in newly established departments at Anadolu University Open Education Faculty.

\section{Findings}

In this study, we reduce our independent variables, which contain strong linear relationships among themselves, to fewer variables through factor analysis. By using the factor loads, we make multiple linear regression with our dependent variable defining the demand for open education. So, let's first explain factor analysis.

Factor analysis is a method used to convert interconnected data structures into independent and fewer new data structures, to reveal common factors by grouping the variables that are assumed to explain an occurrence or event, to group major and minor factors to group variables that affect a formation. We will apply factor analysis to 10 independent variables, described above. We also created a correlation matrix to show that they have strong relationships with each other. We tested a relationship between variables at $1 \%$ significant level and these values were indicated with double stars in the correlation matrix. One of the statistics used to investigate the suitability of the data for factor analysis is Kaiser, Meyer and Olkin. Kaiser, Meyer and Olkin (KMO) have developed a dimension based on simple and partial correlation coefficients. The following measurements are used in this test:

Table 2. Recommendations by Kaiser Meyer Olkin Value

\begin{tabular}{ll}
\hline KMO Measure & Recommendation \\
\hline $\mathbf{0 , 9 0}$ & Excellent \\
\hline $\mathbf{0 , 8 0 +}$ & Good \\
\hline $\mathbf{0 , 7 0 +}$ & Middle \\
\hline $\mathbf{0 , 6 0 +}$ & Weak \\
\hline $\mathbf{0 , 5 0 +}$ & Too weak \\
\hline$<\mathbf{0 , 5 0}$ & Unacceptable \\
\hline
\end{tabular}


One of the tests used to investigate the suitability of the data for factor analysis is the Bartlett test. It tests the possibility of a high correlation between at least some of the variables in the correlation matrix. The null hypothesis is expressed as the unit matrix of the correlation matrix. It requires rejection of the null hypothesis to continue factor analysis. If the null hypothesis is rejected, there are high correlations between the variables. So, the data set is suitable for factor analysis (Kalayc1, 2008).

Table 3. Kaiser Meyer Olkin and Bartlett's Test

\begin{tabular}{llr}
\hline \multicolumn{2}{c}{ KMO and Bartlett's Test } &, 701 \\
\hline Kaiser-Meyer-Olkin Measure of Sampling Adequacy. & 1225,927 \\
\hline Bartlett's Test of Sphericity & Approx. Chi-Square & 45 \\
\cline { 2 - 3 } & $\mathrm{df}$ &, 000 \\
\cline { 2 - 3 }
\end{tabular}

Since the KMO value $(0,701)$ is greater than 0,70 , it is in the middle level. In addition, the result of the Bartlett test $(\mathrm{Sig} .=0.0001<0.05)$ indicates that the analysis is appropriate.

In the Principal Components Method, the first factor explaining the maximum variance between the variables is calculated, then the second factor is calculated to explain the maximum amount of variance remaining. It goes on like this (Kalayc1, 2008). In this method, a linear combination of the number of variables is obtained. These components must be orthogonal and the first component should explain the largest part of the variance of the original variables, while the second should explain the largest part of the remaining variance (Orhunbilge, 2010). Thus, when the contribution of each additional factor to the explanation of the total variance falls below 5 percent, the maximum number of factors is reached (Kalayc1, 2008).

In our study, the first factor shows the total variance $48,704 \%$, the first and second factors together account for $69,518 \%$ of the total variance and $82,969 \%$ of the three factors total factor. This level of disclosure is also quite high. We understand this from the Total Variance Explained table. The last column of the Total Described Variance table contains these explanations, especially since we apply rotation with Varimax to identify factors:

Table 4. Total Variance Explained

\begin{tabular}{|c|c|c|c|c|c|c|c|c|c|}
\hline \multicolumn{10}{|c|}{ Total Variance Explained } \\
\hline \multirow[b]{2}{*}{ 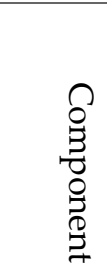 } & \multicolumn{3}{|c|}{ Initial Eigenvalues } & \multicolumn{3}{|c|}{$\begin{array}{l}\text { Extraction Sums of } \\
\text { Squared Loadings }\end{array}$} & \multicolumn{3}{|c|}{$\begin{array}{l}\text { Rotation Sums of Squared } \\
\text { Loadings }\end{array}$} \\
\hline & $\begin{array}{l}\stackrel{-1}{0} \\
\stackrel{D}{D}\end{array}$ & 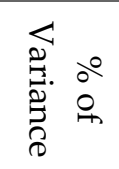 & 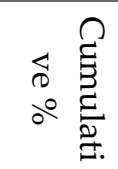 & 官 & 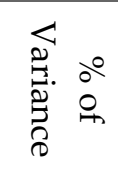 & 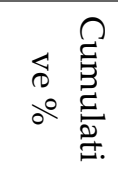 & 年 & 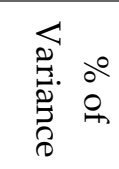 & 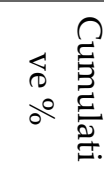 \\
\hline 1 & 4,927 & 49,275 & 49,275 & 4,927 & 49,275 & 49,275 & 4,870 & 48,704 & 48,704 \\
\hline
\end{tabular}




\begin{tabular}{rrrrrrrrrr}
\hline 2 & 2,131 & 21,311 & 70,586 & 2,131 & 21,311 & 70,586 & 2,081 & 20,815 & 69,518 \\
\hline 3 & 1,238 & 12,383 & 82,969 & 1,238 & 12,383 & 82,969 & 1,345 & 13,451 & 82,969 \\
\hline 4 &, 708 & 7,076 & 90,045 & & & & & & \\
\hline 5 &, 597 & 5,975 & 96,020 & & & & & & \\
\hline 6 & 283 & 2,834 & 98,854 & & & & & & \\
\hline 7 &, 077 &, 771 & 99,625 & & & & & & \\
\hline 8 &, 019 &, 192 & 99,816 & & & & & & \\
\hline 9 &, 016 &, 157 & 99,974 & & & & & & \\
\hline 10 &, 003 &, 026 & 100,000 & & & & & & \\
\hline
\end{tabular}

Scree test graph refers to the total variance associated with each factor. Factors up to the point where the graph takes a horizontal shape on the $\mathrm{x}$-axis have the power to explain the total variance (Kalaycl, 2008). Note that in the section up to the 4 th point 3 line indicates the presence of 3 factors.

\section{Scree Plot}

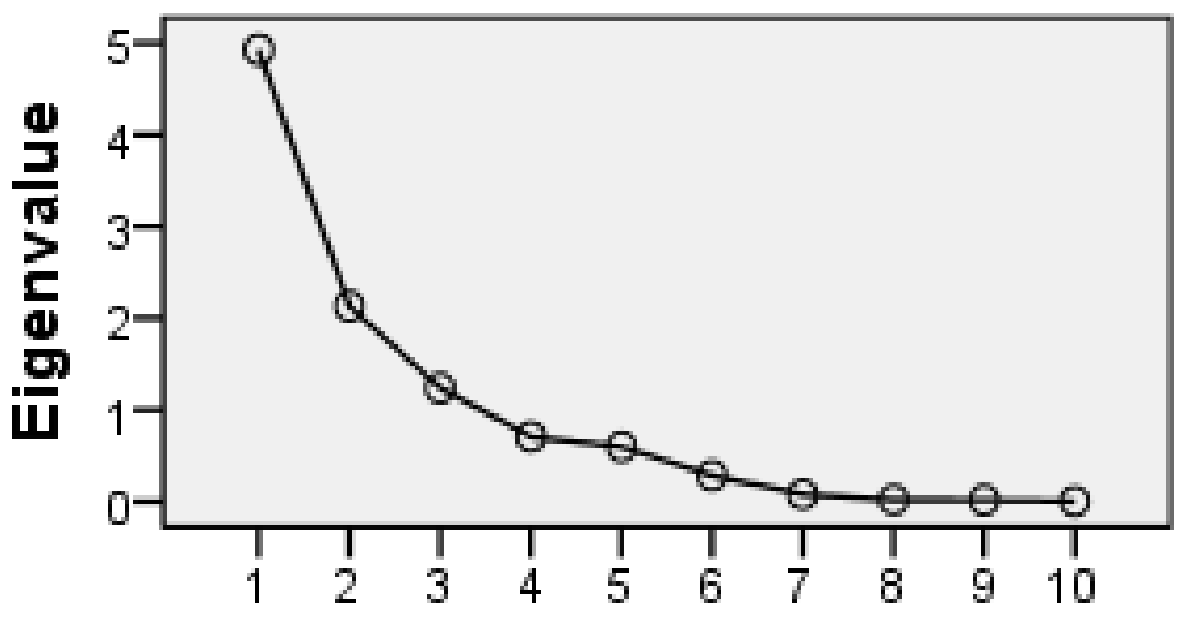

Component Number

Table 5. Component Matrix ${ }^{a}$

\begin{tabular}{|c|c|c|c|}
\hline & \multicolumn{3}{|c|}{ Component } \\
\hline & 1 & 2 & 3 \\
\hline $\mathrm{x} 11$ & ,981 &,- 075 & ,008 \\
\hline x19 & 970 & ,013 & -004 \\
\hline $\mathrm{x} 14$ & ,948 &,- 012 &,- 127 \\
\hline $\mathrm{x} 15$ & ,932 &,- 015 &,- 143 \\
\hline $\mathrm{x} 12$ & 823 & ,112 &,- 140 \\
\hline x13 & ,719 &,- 253 & , 194 \\
\hline $\mathrm{x} 3$ & ,015 & ,970 &,- 172 \\
\hline $\mathrm{x} 1$ & ,069 & ,966 &,- 139 \\
\hline$x 8$ & ,138 & ,133 & ,826 \\
\hline x9 & 193, & 395, & 643 \\
\hline
\end{tabular}

(Extraction Method: Principal Component Analysis. a. 3 components extracted.) 
If a factor has a large weight as an absolute value under which factor, then that variable is closely related to that factor. Weights of 0.50 and above are considered to be quite good (Kalayc1, 2008).

Table 6. Rotated Component Matrix

\begin{tabular}{|c|c|c|c|}
\hline \multicolumn{4}{|c|}{ Rotated Component Matrix ${ }^{a}$} \\
\hline & \multicolumn{3}{|c|}{ Component } \\
\hline & 1 & 2 & 3 \\
\hline x11 & 976 & - 054 & 113 \\
\hline $\mathrm{x} 19$ & ,962 & 034 & , 120 \\
\hline $\mathrm{x} 14$ & ,956 & 039 &,- 007 \\
\hline $\mathrm{x} 15$ & ,942 & 039 &,- 025 \\
\hline $\mathrm{x} 12$ & 827 & 160 &,- 005 \\
\hline $\mathrm{x} 13$ & ,704 &,- 277 & ,217 \\
\hline $\mathrm{x} 3$ &,- 013 & ,983 & ,063 \\
\hline $\mathrm{x} 1$ & , 036 & ,973 & 101 \\
\hline $\mathrm{x} 8$ & 034 &,- 066 & 845 \\
\hline $\mathrm{x} 9$ & 097 & 234 & ,736 \\
\hline
\end{tabular}

(Extraction Method: Principal Component Analysis. Rotation Method: Varimax with Kaiser Normalization. ${ }^{\mathrm{a}}$ ) (a. Rotation converged in 3 iterations.)

The aim of rotation is to create a simple factor structure that can be interpreted meaningfully to researchers. The aim in the Varimax method is to create a factor structure that will make the variable within only one factor. The values above are the first factor since $x 11, x 19, x 14, x 15, x 12$ and $x 13$ are greater than 0.5 . The second factor is $x 3$ and $x 1$ are also greater than 0.5 . Finally, $x 8$ and $x 9$ are the third factor.

\section{Component Plot in Rotated Space}

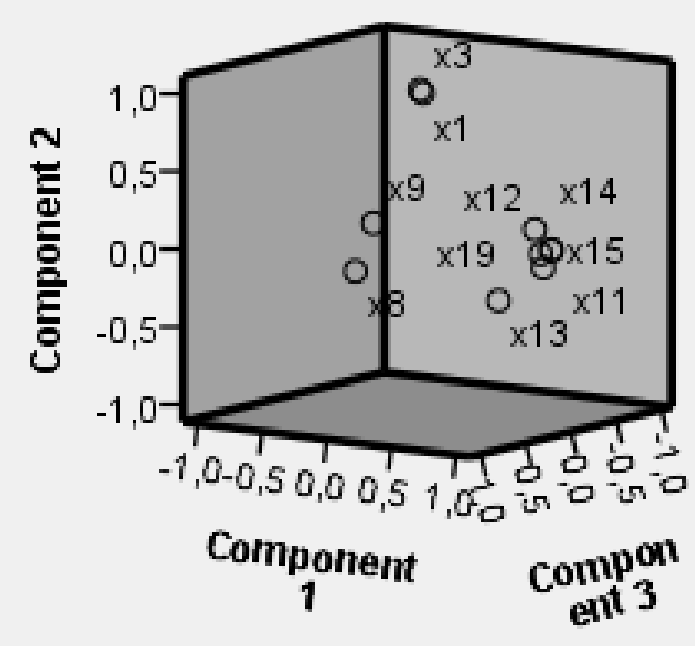


In the above chart, a factor of $x 1$ and $x 3$, a factor of $x 9$ and $x 8$, and the proximity of $x 11, x 12, x 13, x 14, x 15$ and $x 19$ indicate the presence of three factors. According to these results, if we want to name the factors, x11, x12, x13, x14, x15 and x19 can be said to be an economic factor because it defines the economic status of the province. It can be said that $x 1$ and $x 3$ are labor force factors, $x 9$ and $x 8$ are educational factors.

Structural Equality Models (SEM) is a statistical technique used to determine the causal or correlation relationship between observed variables and latent variables (Ersöz, Pınarbaşı, Türker and Yüzükırmızı, 2009).

In this structural equation model, three hidden variables have been formed: economic status, labor force status and educational status of the province. So three factors have emerged. So far, factor analysis was performed depending on their correlation relations. After this stage, factor loadings are considered as explanatory variables and multiple linear regression analyzes are performed.

The first regression model examines the relationship between the factor loadings obtained from factor analysis and the new registry variables of Anadolu University Open Education System.

Table 7. First Regression Model Summary

\begin{tabular}{|c|c|c|c|c|}
\hline \multicolumn{5}{|c|}{ Model Summary } \\
\hline Model & $\mathrm{R}$ & R Square & Adjusted R Square & $\begin{array}{l}\text { Std. Error of the } \\
\text { Estimate }\end{array}$ \\
\hline 1 & ,989a & ,978 & 977 & 578,31563 \\
\hline
\end{tabular}

(a. Predictors: (Constant), REGR factor score 3 for analysis 1, REGR factor score 2 for analysis 1, REGR factor score 1 for analysis 1)

The standard error and the coefficient of significant of the model are given in the model summary table. When 2013 is taken into consideration, the independent variables have a power of $97.7 \%$ to explain the dependent variable, new records, $y 1$.

Table 8. ANOVA of First Regression Model

\begin{tabular}{llrrrrr}
\hline \multicolumn{7}{c}{ ANOVA $^{\mathrm{a}}$} \\
\hline Model & \multicolumn{1}{c}{ F } & \multicolumn{1}{c}{ Sig. } \\
\hline \multirow{2}{*}{1} & Regression & 1157494762,822 & 3 & 385831587,607 & 1153,634 & ${ }^{000^{\mathrm{b}}}$ \\
\cline { 2 - 8 } & Residual & 25752570,387 & 77 & 334448,966 & & \\
\cline { 2 - 7 } & Total & 1183247333,210 & 80 & & & \\
\hline
\end{tabular}

(a. Dependent Variable: y1, b. Predictors: (Constant), REGR factor score 3 for analysis 1, REGR factor score 2 for analysis 1, REGR factor score 1 for analysis 1 ) 
ANOVA table shows that the model is significant. In addition, the significance of the coefficients is understood from the Table below. The calculated $t$ values and their significance levels are in the last two columns of this table. It is seen that the load of the second workforce factor is meaningful at $5 \%$ significant level, because of 0.048 $<0.05$. Other factor loads can be said to be significant at less than 0.0001 .

Table 9. Coefficients of First Regression Model

\begin{tabular}{|c|c|c|c|c|c|c|}
\hline \multicolumn{7}{|c|}{ Coefficients ${ }^{a}$} \\
\hline \multirow{2}{*}{\multicolumn{2}{|c|}{ Model }} & \multicolumn{2}{|c|}{$\begin{array}{l}\text { Unstandardized } \\
\text { Coefficients }\end{array}$} & \multirow{2}{*}{$\begin{array}{c}\text { Standardized } \\
\text { Coefficients } \\
\text { Beta }\end{array}$} & \multirow[t]{2}{*}{$t$} & \multirow[t]{2}{*}{ Sig. } \\
\hline & & $\mathrm{B}$ & Std. Error & & & \\
\hline \multirow[t]{4}{*}{1} & (Constant) & 1886,099 & 64,257 & & 29,352 & ,000 \\
\hline & $\begin{array}{l}\text { REGR factor score } 1 \\
\text { for analysis } 1\end{array}$ & 3782,581 & 64,658 & 984 & 58,502 & ,000 \\
\hline & $\begin{array}{l}\text { REGR factor score } 2 \\
\text { for analysis } 1\end{array}$ & $-129,986$ & 64,658 &,- 034 & $-2,010$ & ,048 \\
\hline & $\begin{array}{l}\text { REGR factor score } 3 \\
\text { for analysis } 1\end{array}$ & 379,300 & 64,658 & ,099 & 5,866 & ,000 \\
\hline
\end{tabular}

(a. Dependent Variable: y1)

According to $\mathrm{F}$ test in ANOVA table, the model is statistically significant. The factor of the first factor load, which expresses the economic level of the city, is the highest in the model and positive with a value of 3782,581 . The coefficient of labor factor loadings is negative with a value of $-129,986$. The coefficient of the load of training factor is positive with a value of 379.3 .

When the analysis values are examined, the most important factor affecting the new records positively is the economic performance of the province and the other is the educational situation. The combination of employment rates and labor force ratios of the province has created a latent variable and is named as the labor force. this latent variable affects the new records in a negative way.

Our second regression relationship is among the factor loads obtained from factor analysis and additional placement variables.

Table 10. Second Regression Model Summary

\begin{tabular}{|c|c|c|c|c|}
\hline \multicolumn{5}{|c|}{ Model Summary } \\
\hline Model & $\mathrm{R}$ & R Square & Adjusted R Square & $\begin{array}{l}\text { Std. Error of the } \\
\text { Estimate }\end{array}$ \\
\hline 1 & 988a & 975 & ,974 & 122,49490 \\
\hline
\end{tabular}


Factor loads are independent variables and additional placement (y2) is dependent variable. The independent variables have a power of $97.4 \%$ to explain the dependent variable.

Table 11. ANOVA of Second Regression Model

\begin{tabular}{lllrrrrr}
\hline \multirow{2}{*}{ Model } & \multicolumn{5}{c}{ ANOVA $^{\mathrm{a}}$} \\
& & $\begin{array}{c}\text { Sum of } \\
\text { Squares }\end{array}$ & $\mathrm{df}$ & Mean Square & $\mathrm{F}$ & Sig. \\
\hline \multirow{2}{*}{1} & Regression & 45359408,749 & 3 & 15119802,916 & 1007,651 &, $000^{\mathrm{b}}$ \\
\cline { 2 - 7 } & Residual & 1155384,979 & 77 & 15005,000 & & \\
\cline { 2 - 7 } & Total & 46514793,728 & 80 & & & \\
\hline
\end{tabular}

(a. Dependent Variable: y2

b. Predictors: (Constant), REGR factor score 3 for analysis 1, REGR factor score 2 for analysis 1, REGR factor score 1 for analysis 1 )

According to the F test, the model is statistically significant. In this analysis, the coefficient of the 1st factor load, i.e. the economic level of the city, is the highest in the model and positive with a value of 747,515 . The coefficient of the labor factor loadings is negative with a value of $-48,012$. The coefficient of the load of the training factor is positive with a value of 76.87 .

According to the results of this analysis, the most important factor that positively affects the demands of open education, considered as additional placement, is the economic performance of the province. Another factor is education. The latent variable, which is formed by the combination of employment and labor rates of the province and which we call the labor force, negatively affects the new records. We can tell these explanations according to the size and sign of the coefficients.

Table 12. Coefficients of Second Regression Model

\begin{tabular}{|c|c|c|c|c|c|c|}
\hline \multicolumn{7}{|c|}{ Coefficients $^{a}$} \\
\hline \multirow{2}{*}{\multicolumn{2}{|c|}{ Model }} & \multicolumn{2}{|c|}{$\begin{array}{l}\text { Unstandardized } \\
\text { Coefficients }\end{array}$} & \multirow{2}{*}{$\begin{array}{c}\text { Standardized } \\
\text { Coefficients } \\
\text { Beta } \\
\end{array}$} & \multirow[t]{2}{*}{$\mathrm{t}$} & \multirow[t]{2}{*}{ Sig. } \\
\hline & & $\mathrm{B}$ & Std. Error & & & \\
\hline \multirow[t]{4}{*}{1} & (Constant) & 392,420 & 13,611 & & 28,832 & , 000 \\
\hline & $\begin{array}{l}\text { REGR factor score } 1 \\
\text { for analysis } 1\end{array}$ & 747,515 & 13,695 & 980 & 54,582 &, 000 \\
\hline & $\begin{array}{l}\text { REGR factor score } 2 \\
\text { for analysis } 1\end{array}$ & $-48,012$ & 13,695 &,- 063 & $-3,506$ & ,001 \\
\hline & $\begin{array}{l}\text { REGR factor score } 3 \\
\text { for analysis } 1\end{array}$ & 76,870 & 13,695 & 101 & 5,613 & ,000 \\
\hline
\end{tabular}

(a. Dependent Variable: y2)

\section{Results}


As it is known, human capital theory considers the education as the main source of human capital and approaches it as a positive and direct effect for an individual's lifetime income while decreasing the risk of unemployment (Zafar and Hina, 2000). In general, the phenomenon of lifelong education comes to the fore with this view accepted by all economists, educators, politicians and public administrators. It is a fact that Anadolu University Open Education System, which uses high-end open and distance education technologies, is a key source of life-long education with minimum costs.

In this study, we used new registry and additional registry variables in Anadolu University Open Education System for 2013 as a dependent variable. In addition, there are 10 interrelated independent variables that can be grouped as a result of high correlations. Therefore, by combining factor analysis and multiple regression analysis, we created two separate path analyzes for two dependent variables. In both analyzes, we observed that the economic and educational factors of the province had a positive effect on the demand directed to the Open Education System of Anadolu University, whereas the labor force factor had a negative effect on the demand. Finally, considering the magnitude of the coefficients, we have concluded that the economic situation of the province is much more effective than the other two factors.

\section{References}

Barro, R. J. (1991). Economic Growth in a Cross Section of Countries, The Quarterly Journal of Economics, 106(2), 407-443.

Barro, R. J. \& Sala-i-Martin X. (1995) Economic Growth, London: The MIT Press, 431.

Beşkaya, A., Savaş, B. \&Şamiloğlu, F. (2010). The Impact of Education on Economic Growth in Turkey, Süleyman Demirel Üniversitesi İktisadi ve İdari Bilimler Fakültesi Dergisi, 15 (3), 43-62.

Bils, M. \& Klenow, P. J. (2000). Does Schooling Cause Growth?, The American Economic Review, 90(5), 1160-1183.

Brannick, M. T. (2009). Path Analysis, Retrieved December 20, 2009 from http://luna.cas.usf.edu/ mbrannic/files/regression/Pathan.html

Çalışkan, Ş., Karabacak, M. \& Meçik, O. (2013). Türkiye' de Eğitim- Ekonomik Büyüme İlişkisi: 1923-2011 (Kantitatif Bir Yaklaşım), Yönetim Bilimleri Dergisi, 11(2), 29-48.

Ersöz, S., Pınarbaşı, M., Türker, A. K. \& Yüzükırmızı, M. (2009). Hizmet Kalitesinin Servqual Metodu ile Ölçümü ve Sonuçların Yapısal Eşitlik Modelleri ile Analizi: Öğretmenevi Uygulaması, Int. J. Eng. Research \& Development, 1(1), January, 19-27

Kalaycı, Ş. (2008). SPSS Uygulamalı Çok Değişkenli İstatistik Teknikleri, Asil Yayın Dağıtım

Kavak, Y. (1990). Kalkınmada Öncelikli Yörelerdeki Yükseköğretim Kurumlarının Çevreye Dönük Faaliyetleri, Türkiye Ticaret, Sanayi, Deniz Ticaret Odaları ve Ticaret Borsaları, 
TOBB 40 yıl, TOBB yayın no: Genel 157, Ar-Ge 67, ISBN: 975-512-053-X, Afşaroğlu Matbaası, Ankara

Kar, M. \& Ağır, H. (2003) Türkiye'de Beşerî Sermaye ve Ekonomik Büyüme: Nedensellik Testi, Tebliğ, II. Ulusal Bilgi, Ekonomi ve Yönetim Kongresi, 17-18 Mayıs 2003, Kocaeli Üniversitesi, Derbent-İzmit.

Kasliwal, P. (1995). Development Economics, S. Western Collage Publishing, Ohio.

Mincer, J. (1996). Economic Development, Growth of Human Capital, and the Dynamics of the Wage Structure, Journal of Economic Growth, 1, 29-48.

OECD (1995). Education at a Glance: OECD Indicators. Paris, OECD CERI. 39

Orhunbilge, A. N. (2010). Çok Değişkenli İstatistiksel Yöntemler, İstanbul Üniversitesi Yayn No: 4942, İşletme Fakültesi Yayın No: 286, ISBN: 978-975-404-870-4

Özgür, E. (2005). Türkiye'de Kalkınmaya Yönelik Eğitim Politikaları ve Eğitim Yatırımlarının Geri Dönüşü, Basılmamış Yüksek Lisans Tezi, Eskişehir Osmangazi Üniversitesi, Eskişehir.

Pek, H. (1999). Nedensel Modeller, Yayımlanmamış Yüksek Lisans Tezi, Gazi Üniversitesi, Fen Bilimleri Enstitüsü.

Seyidoğlu, H. (1993). Uluslararası İktisat, Gizem Yayınları, 9. Baskı, İstanbul.

Şimşek, A. (2015). Erişilebilir Şehirler ve Bölgeler: Erişilebilirliğin Bölgesel Kalkınmaya Etkisi ve İller Bazında Erişilebilirlik endeksinin Geliştirilmesi, T. C. Kalkınma Bakanlığı, Bölgesel Gelişme ve Yapısal Uyum Müdürlüğü, ISBN: 978-605-9041-59-1, Yayın No: 2945

Şimşek, M. \& Kadılar, C. (2010). Türkiye'de Beşerî Sermaye, İhracat ve Ekonomik Büyüme Arasındaki İlişkinin Nedensellik Analizi, Cumhuriyet Üniversitesi İktisadi ve İdari Bilimler Fakültesi, 11(1), 115-140.

Taban, S. \& Kar, M. (2006) Beşerî Sermaye ve Ekonomik Büyüme: Nedensellik Analizi, 19692001, Anadolu Üniversitesi Sosyal Bilimler Dergisi, 6(1), 159-181.

Taş, U. \& Yenilmez, F. (2008). Türkiye'de Eğitimin Kalkınma Üzerindeki Rolü ve Eğitim Yatırımlarının Geri Dönüş Oranı, Eskişehir Osmangazi Üniversitesi, Sosyal Bilimler Dergisi, 9(1), 155-186.

Zafar M. N. \& Hina N. (2000). Education and Earnings in Pakistan, Pakistan Institute of Development Economics, No: 177, 1. 